\title{
Market integration of renewable energies through direct marketing - lessons learned from the German market premium scheme
}

\author{
Alexandra Purkus ${ }^{1 *}$, Erik Gawel ${ }^{1,2}$, Marc Deissenroth $^{3}$, Kristina Nienhaus $^{3}$ and Sandra Wassermann ${ }^{4}$
}

\begin{abstract}
Background: Increasing the market and system integration of renewable energy sources (RES) is regarded as key to reducing the costs of RES support and transforming the electricity system. In several EU countries, feed-in premium schemes have been implemented to better align RES production with electricity prices and to enhance the efficiency of RES marketing by increasing direct participation of producers in electricity markets. This paper examines the lessons learned from the German market premium scheme, which was introduced in the Renewable Energy Sources Act 2012 as an optional alternative to feed-in tariffs. The 2014 reform of that law has made direct marketing mandatory except for small RES plants, thus establishing the sliding market premium as the new primary instrument of RES support.
\end{abstract}

Methods: Combining a qualitative economic analysis with insights from sociological research on direct marketing and simulation results from agent-based modelling, we evaluate how well the optional market premium has performed in setting incentives for demand-oriented RES production and efficient marketing of RES electricity. Furthermore, we examine what efficiency gains can be realistically expected from the changes implemented in 2014, and discuss whether the direct marketing model adopted in Germany is a promising approach for improving the market integration of RES.

Results: We find that direct marketing has made a positive contribution to the marketing efficiency of dispatchable RES; for intermittent RES, it provides few structural changes compared to marketing through transmission system operators. The benefits of a greater demand-orientation of RES feed-in remain limited when considering the extent to which load shifting is incentivised. For intermittent RES in particular, incentives for demand-oriented feed-in are only effective in times of negative electricity prices when voluntary curtailment is encouraged.

Conclusions: For the further development of mechanisms to support greater market proximity, differentiating between the various RES according to their ability to respond to electricity price signals can prove advantageous. Also, objectives such as improving security of supply and reducing the costs of transforming the electricity system cannot be reached through RES market integration efforts alone but require an adaptation of electricity market conditions to the requirements of RES.

Keywords: Renewable energy policy; Market integration; Feed-in premium; Direct marketing

\footnotetext{
* Correspondence: alexandra.purkus@ufz.de

'Department of Economics, Helmholtz Centre for Environmental Research - UFZ, Permoser Str. 15, Leipzig 04318, Germany

Full list of author information is available at the end of the article
} 


\section{Background \\ RES market integration - objectives and instrumental implementation}

As electricity generation from renewable energy sources (RES) continues to expand in Europe, EU member states are faced with the challenge of integrating the growing proportion of renewables, and especially intermittent renewables, into existing energy systems and electricity markets $[1,2]$. In this process, increasing the market integration of RES is viewed as an important step towards improving the alignment of RES feed-in to scarcity signals in electricity markets and systems, thus containing the costs of RES expansion; these relate not only to the costs of supporting RES but also to the wider costs of transforming the electricity system [2,3]. The new EU energy aid guidelines, for instance, stress that marketbased mechanisms should promote the 'transition to a cost-effective delivery' (p. 23) and highlight the importance of direct market participation and the assumption of market responsibilities by RES producers [4]. In principle, it appears sensible to differentiate between two different dimensions of market integration (see Table 1) [5-7]. Firstly, market integration aims for a stronger alignment of RES feed-in to price signals in the electricity market as well as an efficient marketing of RES electricity [5,6]. Incentives for this dimension of market integration can be implemented in RES policy instruments where prices are administered by the state, by changing from a feed-in tariff which is paid independently from market prices to a feed-in premium model where electricity prices influence total remuneration. This approach is currently pursued by several EU member states using various different design options [8,9]. While fixed feed-in premiums offer RES producers a set bonus on top of the market price, sliding premiums balance out the difference between reference prices and average market prices [10]. Here, total remuneration remains based on statedetermined prices, as is the case for fixed feed-in tariffs, so that the long-term market risks for producers of RES remain comparatively low. The second dimension of market integration, on the other hand, encompasses a competitive determination of the remuneration and a competitive steering of investment decisions [11,12]. This involves a transition to treating RES producers as regular market players with system responsibility, with competitive support mechanisms and electricity market revenues playing a significant role in their refinancing. At present, discussions about the instrumental implementation of this dimension of market integration focus primarily on competitive bidding processes, given that the new EU guidelines on state aid express a clear preference for this instrument type [4]. A further distinction is necessary between the market integration and system integration of RES - the latter aims at improving RES' contribution to grid stability $[1,13]$ but is not the focus of this article.

One example of a sliding feed-in premium scheme is the German market premium model, which was initially introduced into the RES support regime in 2012 as an optional alternative to the fixed feed-in tariff in order to set incentives for demand-oriented RES feed-in and efficient marketing of electricity from RES. With the introduction of the amended Renewable Energy Sources Act (EEG) 2014, this approach was further extended by making

Table 1 An overview of the objectives of market integration of renewable energy sources

\begin{tabular}{|c|c|c|}
\hline Market integration objectives & Dimensions of achievement of objectives & Contributions to overarching objectives \\
\hline \multirow{6}{*}{$\begin{array}{l}\text { Demand-oriented generation of RES } \\
\text { electricity and increased flexibility of } \\
\text { RES plants }\end{array}$} & $\begin{array}{l}\text { Prevention of surplus supply situations via voluntary } \\
\text { curtailment in times of negative electricity prices }\end{array}$ & $\begin{array}{l}\text { Contribution of RES to security of supply is } \\
\text { increased; }\end{array}$ \\
\hline & $\begin{array}{l}\text { Shift of feed-in to times when } \\
\text { demand is strong and prices are high: }\end{array}$ & $\begin{array}{l}\text { Costs of RES promotion are reduced through an } \\
\text { increase in RES market value; }\end{array}$ \\
\hline & $\begin{array}{l}\text { - Intermittent RES: Maintenance planning, installation } \\
\text { design oriented towards market value and system } \\
\text { requirements }\end{array}$ & $\begin{array}{l}\text { Cost reductions in the overall system (e.g. lower } \\
\text { balancing energy prices and system integration } \\
\text { costs) }\end{array}$ \\
\hline & - Dispatchable RES: targeted load shifting & \\
\hline & Increased remote controllability of RES installations & \\
\hline & $\begin{array}{l}\text { Participation of RES installations in the balancing energy } \\
\text { market }\end{array}$ & \\
\hline \multirow[t]{3}{*}{ Efficient marketing of RES electricity } & Reduced transaction costs of marketing RES electricity & RES promotion costs are reduced \\
\hline & $\begin{array}{l}\text { Increased forecasting quality and reduction of costs of } \\
\text { procuring balancing energy }\end{array}$ & \\
\hline & Competition for efficient marketing forms & \\
\hline \multirow{2}{*}{$\begin{array}{l}\text { Market-driven production and } \\
\text { investment decisions }\end{array}$} & Competitive determination of RES remuneration & RES expansion costs are reduced \\
\hline & RES producers become regular market players & \\
\hline
\end{tabular}


direct marketing mandatory except for small plants, while elevating the market premium scheme to the standard remuneration model. In the literature, assessments of the market premium scheme come to divided conclusions. While some studies evaluate the promotion of market integration via the sliding market premium positively $[6,14,15]$, others are critical of the instrument. On the one hand, market-determined incentives for RES producers are regarded as insufficient to promote market integration and reduce the costs of RES support $[11,12,16,17]$. On the other hand, however, critics question the usefulness of a direct marketing-driven integration of intermittent RES into the marginal cost-based electricity market, which may be structurally unsuitable to secure their long-term refinancing [18-21]. Furthermore, there are trade-offs between the objective of exposing RES producers to market price signals in order to increase the efficiency of production and investment decisions on the one hand, and the creation of a secure planning basis for RES investors, which is crucial to achieve a comprehensive transformation to an RES-based electricity system, on the other [13]. If RES producers carry a high share of market risks, this would also tend to increase the costs of supporting the implementation of RES objectives, because higher risks have to be compensated by higher risk premiums in the remuneration [22-24].

The following article evaluates experiences gained in Germany from the introduction of the sliding market premium and discusses to what extent this form of government-supported direct marketing can serve as a promising instrument to promote the integration of RES into the electricity market. The article begins with an outline of the design of the sliding market premium instrument and supplementary regulations on the promotion of market integration in the EEG 2014, as well as an overview of the development of participation in direct marketing. This is followed by an evaluation of experiences gained with the market premium under the EEG 2012. Building on this, we examine to what extent the new regulations set forth in the EEG 2014 can be expected to make a greater contribution to the market integration objectives of realising a demand-oriented feed-in of RES and efficient marketing.

\section{Methods}

As a sliding feed-in premium with state-administered prices, the market premium scheme does not aim for a competitive control of RES investments [9,15]. Therefore, our assessment of the scheme's performance focusses on the market integration objectives of realising a demandoriented generation of RES electricity and increased flexibility of RES plants, as well as an efficient marketing or RES electricity. Based on existing literature, measures were identified which contribute to these objectives; these are summarised in Table 1. Below, we discuss whether the market premium scheme sets incentives for the adoption of these measures and whether contributions to market integration objectives are effective and efficient. To conduct this assessment, we review literature findings and available data, and analyse the impact of incentives on RES producers' behaviour. This qualitative analysis is complemented by simulation results from the agentbased simulation model AMIRIS, which was developed at the Institute of Engineering Thermodynamics at the German Aerospace Center (DLR) in Stuttgart [25,26] The special nature of this article is an explicit interdisciplinary approach to the research topic which attempts to integrate existing studies from sociological research on markets [27], energy economics [9] and agent-based modelling [26].

\section{Results and discussion}

Promoting market integration via the German market premium model

In the market premium model under the Renewable Energy Sources Act (EEG), producers of electricity from RES receive the difference between technology-specific reference prices and the actual, likewise technologyspecific, monthly average market price (EEG 2014 Annex 1). Under the EEG 2012, installation operators had the option of switching between direct marketing and feed-in tariffs, where the sale of electricity from RES is centrally managed by transmission system operators (TSOs). This is no longer possible under the EEG 2014. Only installations with a maximum installed capacity of $500 \mathrm{~kW}$ are now eligible to receive the feed-in tariff; and as of 2016, the obligation to participate in direct marketing will be extended to all installations with a capacity of over $100 \mathrm{~kW}$ (\$ 37 (2) EEG 2014). In exceptional cases, operators will still be able to fall back on feed-in tariffs, with a $20 \%$ reduction in remuneration rates $(\mathbb{S} 38$ EEG 2014). The so-called 'green electricity privilege' provided under $\mathbb{} 39$ EEG 2012, whereby electricity suppliers benefitted from EEG surcharge reductions if a certain proportion of their electricity supply was sourced from directly marketed RES, has also been removed from the new EEG. A further amendment relates to the fact that under the EEG 2012, RES producers were eligible for a separately calculated management premium to compensate for the additional costs of trading and providing balancing energy. Under the EEG 2014, in contrast, the management premium is implicit in the reference prices. For dispatchable renewables, this is reflected by a reduction of 0.2 cents $/ \mathrm{kWh}$ in the reference price on which the fixed feedin tariff is based; while for intermittent renewables, the reduction is 0.4 cents $/ \mathrm{kWh}$ ( $\$ 37$ (3) EEG 2014). At the same time, the remote control capability of RES 
installations, which was incentivised under the EEG 2012 by offering higher management premiums for installations fitted with appropriate systems, will now be a requirement for payment of the market premium $(\S 35$ sentence 1 no. 2 in conjunction with $\S 36$ (1) EEG 2014).

As a measure aimed at strengthening the demandorientation of all renewable energy sources, the EEG 2014 also introduces cuts in financial support in times of negative prices: In the case of installations commissioned after 1 January 2016, the reference prices on which the remuneration is based are to be reduced to zero when the value of the hourly contracts on the EPEX Spot exchange is negative in at least six consecutive hours (\$24 EEG 2014). Given that installations with an installed capacity of less than $500 \mathrm{~kW}$ are exempt, this regulation applies only to larger installations for which direct marketing is obligatory ( $\$ 24$ (3) EEG 2014). As was the case under the EEG 2012, the market premium for biogas plants will be bolstered by a capacity-oriented flexibility premium ( $\S 52$ to 54 EEG 2014). In addition, for biogas installations with a capacity exceeding $100 \mathrm{~kW}$, entitlement to feed-in tariff or premium payments has been limited to the share of the annual amount of electricity generated which corresponds to a power rating of $50 \%$ of the installed electric capacity ( $\$ 47$ (1) EEG 2014), a move intended to guarantee flexible plant operations.

Meanwhile, the transition to a more market-driven steering of investment decisions is supported in the EEG 2014 by the proposed switch to a competitive bidding process, which is geared towards establishing a competitive determination of remuneration by 2017 at the latest ( $\$ 2$ (5) EEG 2014). The details of its design are still unclear [28], but the model is to be tested on ground-mounted solar installations (§ 55 EEG 2014).

\section{Experiences with the market premium under the EEG 2012: participation in direct marketing}

Since its introduction in 2012, the market premium has successfully increased participation in direct marketing (see Figure 1): In April 2014, a total of 49\% of the installed capacity eligible for support under the EEG was marketed under the market premium scheme $[29,30]$. At the same time, the green electricity privilege, as an alternative form of direct marketing, was largely replaced while the option 'other forms of direct marketing' without remuneration is practically irrelevant (see Figure 2). Initially, a high proportion of wind power producers in particular switched to the optional market premium, but in the meantime participation among other RES producers has also increased [9,31]: In April 2014, almost 60\% of biomass installations were taking advantage of the model; and as much as $13 \%$ of solar installations were participating (see Figure 2). Nonetheless, the success of the sliding market premium can only really be measured by its contribution to the actual market integration objectives.

\section{Experiences with the market premium under the EEG 2012: efficient marketing of RES electricity?}

Under the fixed feed-in tariff system, quantities of RES electricity are traded on the day-ahead or intraday spot market in accordance with the provisions of the Equalisation Scheme Ordinance ( $\$ 2$ AusglMechV). By comparison, the sliding market premium would lead to more efficient marketing of RES if (a) direct marketing reduces the transaction costs of market participation, (b) balancing energy costs can be reduced as a result of better RES feed-in forecasts and better management of plant portfolios, e.g. by taking advantage of the ability to control plants remotely or (c) innovative forms of marketing can increase prices obtained for renewables by optimising the choice of markets (e.g. intraday and day-ahead spot market, balancing market, bilateral overthe-counter contracts) (see Table 1). Whether this applies to the market premium model will be examined in the following.

The majority of RES installation operators are not conventional players in the established energy sector and, as a result, most of them have neither infrastructure nor the knowledge required to sell the electricity they produce on the central electricity markets themselves. Introducing RES installation operators to the market was therefore only possible through electricity traders (hereafter referred to as 'direct marketers'). They act as service providers to RES installation operators and in that function offer a broad range of services such as preparing feed-in forecasts, communicating schedules to the grid operators as well as financially compensating for deviations or purchasing additional electricity to make up the scheduled amount. Based on their RES supply forecasts and expected electricity prices, these traders take the initial decision on behalf of the installation operator as to whether to remain within the feed-in tariff scheme or to market directly. In the latter case, they determine the time, the quantity and the market on which RES electricity will be offered for sale. Direct marketers also have access to the specific infrastructure needed to be able to trade on the energy exchange [25].

Regarding the reduction of transaction costs, compared with selling through TSOs, it can be said that initially additional costs are incurred because the TSOs still market the quantities of electricity in the feed-in tariff scheme. In addition, marketing costs are subject to economies of scale because fixed costs make up a large share of those costs $[18,20,32]$. Also, the larger the 


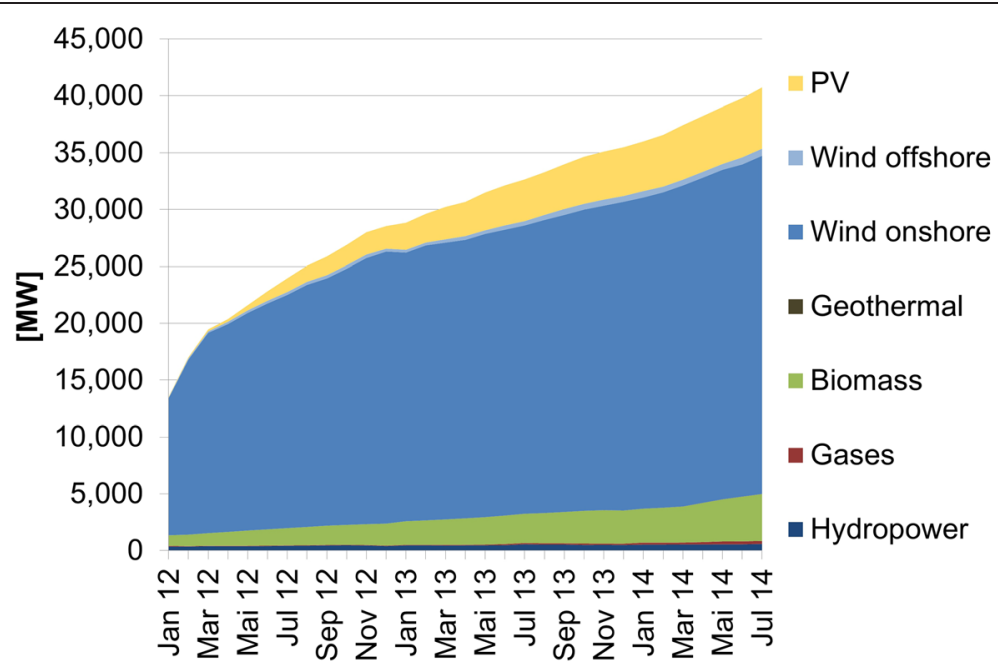

Figure 1 Development of installed capacity in the market premium model (January 2012 - July 2014). 'Gases' encompass landfill, sewage and mining gases. Authors' representation based on 50Hertz et al. 2014 [29].

management portfolio the lower the costs of balancing energy will be, because larger portfolios are associated with higher forecast accuracy [6]. This suggests that in terms of transaction costs, large direct marketers come closest to TSOs.

An approximate value for the additional costs of direct marketing under the market premium scheme is provided by the management premium: In 2012, this amounted to approximately 467 million euros, while in 2013 an estimated 354 to 400 million euros were paid out due to a reduction in management premium rates [33-35]. ${ }^{\text {a }}$ However, the management premium primarily acts as an indicator for the additional support costs associated with direct marketing, rather than for actual transaction costs. Especially in 2012, it was found that an overcompensation of the costs of direct marketing led to high windfall profits, subsequently giving rise to stronger cuts in the management premium rates for intermittent RES [36]. While the management premium pursuant to EEG 2012 forms the essential basis of direct marketing business models [18,37], its degressive design increases cost pressure on marketers over time.

When it comes to the marketing of wind and photovoltaics (PV), the marketing channels used are mainly

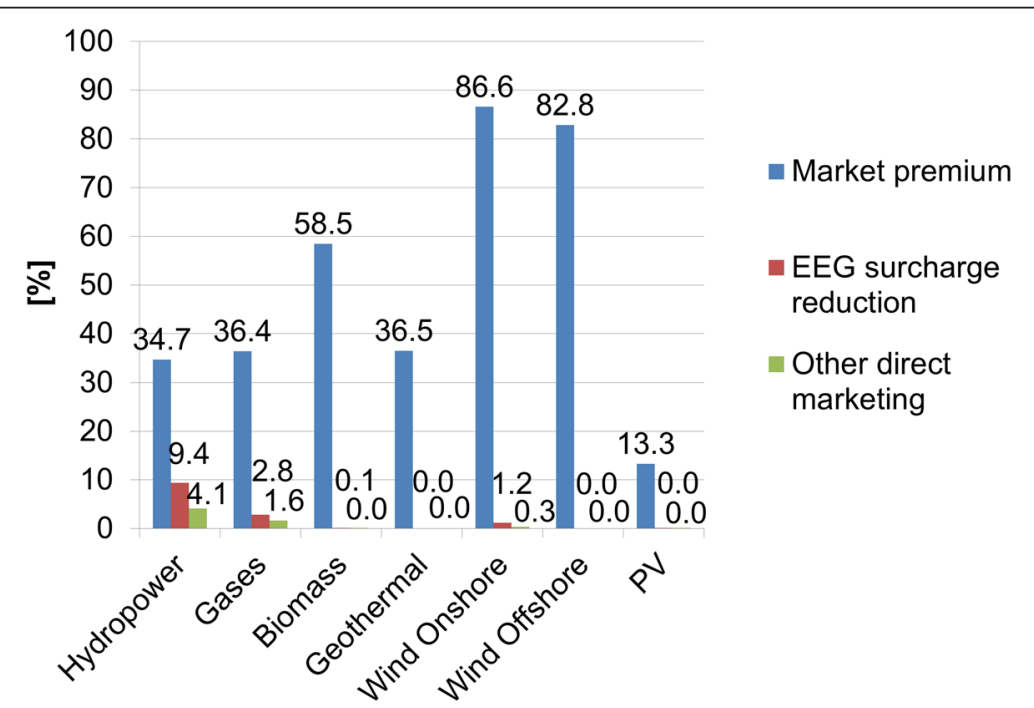

Figure 2 Direct marketing share of the total installed capacity eligible for EEG remuneration (April 2014). 'Gases' encompass landfill, sewage and mining gases. Authors' representation based on 50Hertz et al.; Bundesnetzagentur [29,30]. 
the same as those used by TSOs, i.e. the intraday and day-ahead spot market. This choice is structurally supported by the market premium because spot market prices are used to calculate the market value, and therefore selling on other markets would entail higher levels of revenue risk [6,38]. Biomass installations, on the other hand, show greater participation in balancing markets [6,39]. In principle, differences in flexibility options available to biomass installations in combination with heat utilisation concepts mean that they require more individualised marketing concepts than other RES, so that direct marketing is likely to increase efficiency. In the case of intermittent RES, marketing innovations can be found e.g. in the establishment of RES networks forming virtual power plants, which have spread rapidly [40]. However, targeted marketing of the 'green power' characteristic, as promoted by the green electricity privilege, is not possible under the market premium model ( $\$ 56$ (2) EEG 2012 and $\S 80$ (2) EEG 2014).

Summing up, it can be said that the efficiency benefits that have been achieved with the marketing of wind and PV are mainly attributable to the fact that not only new installations but also existing ones were incentivised to provide for remote control capability and availability of real-time data [6]. However, the marketing channels used are largely similar to those employed by TSOs, with the exception of bioenergy and hydropower generators, for whom the supply of balancing energy is profitable. At present, direct marketing also leads to increases in the transaction costs of RES marketing. A lowering of these costs to a level that is comparable with marketing through TSOs alone could be achieved primarily by exploiting economies of scale. However, corresponding stronger price competition between direct marketers could promote processes of concentration [18,25,38].

\section{Experiences with the market premium under the EEG 2012: incentives for demand-oriented RES production and flexibility?}

A more demand-driven feed-in and greater flexibility in RES production can be achieved when the market premium sets incentives to encourage (a) voluntary curtailment in times of negative electricity prices, (b) in the case of intermittent RES, electricity price-oriented maintenance planning and plant designs that are oriented towards a maximisation of market value and aligned with system requirements, (c) targeted load shifting of dispatchable renewables, (d) increased remote control capability of RES installations (cf. also (b) in the section on efficient RES marketing above) and (e) participation of RES producers in the balancing energy market (see Table 1). Relevant factors for the analysis are not only whether these measures are taken but whether in this form they contribute to the overall objectives of security of supply and cost reduction.

For intermittent RES with near-zero marginal costs, incentives are set to make limited bids and/or to encourage curtailment in times of strongly negative electricity prices [6,41]. Voluntary curtailment becomes profitable when electricity traders participating in the spot market have to pay buyers a higher amount than that which is expected from the market premium payment including the management premium [9]. Currently, for example, wind energy plants in direct marketing curtail their production at negative prices of approximately $-€ 65 / \mathrm{MWh}$ [42]. Their ability to respond depends upon the remote control capability of the installation, which has been growing since 2013 due, among other things, to corresponding incentives in the management premium [6]. Apart from optimising maintenance planning, intermittent RES have few other incentives for load shifting $[9,20]$. Price signals are either too low or not consistent enough to make it worthwhile to base decisions about the location and the design of installations on market value rather than on energy yield, or to stimulate investment in weak-wind installations or east-west facing PV systems $[43,44]$. What is more, the advantages of the market value of alternative installation concepts are being eroded by the increasing number of relevant suppliers [18]. In the case of balancing markets, prequalification of intermittent RES is only possible to a limited extent at present $[5,38]$.

So far, there are no studies available on actual changes in feed-in behaviour for dispatchable renewables. Basically, the market premium sets incentives for voluntary curtailment when electricity prices fall below the difference between the marginal costs of production and the expected market premium including the management premium. For biogas plants, the uptake of the flexibility premium provides insight into whether the conditions for a demand-based, flexible operation are at least in existence [45,46]: In April 2014, 370 installations with approximately $216 \mathrm{MW}_{\text {el }}$ claimed the flexibility premium, which corresponds to roughly $11 \%$ of the installed biogas and biomethane capacities participating in direct marketing [39]. After a slow start in 2012, the use of the flexibility premium is meanwhile increasing rapidly; the delay in uptake is explained by the fact that power plant flexibilisation is associated with financial investments and high information requirements [46].

Next to hydropower installations, biomass installations are the most active RES producers on the electricity balancing market. In April 2014, 24\% of the directly marketed biomass power capacity and $43 \%$ of the directly marketed hydropower capacity were correspondingly pre-qualified. So far, mostly negative balancing energy is supplied $[39,46]$. Figure 3 gives an example of 
how biomass installation operators could generate additional revenues through participation in direct marketing including the balancing market for negative balancing energy. The figure shows the results of a simulation of the agent-based simulation model AMIRIS, which is being developed at the Institute of Engineering Thermodynamics of the German Aerospace Center (DLR) in Stuttgart [25]. Especially for solid fuel-based thermal power plants ${ }^{\mathrm{b}}$ and large biogas installations, the potentially achievable additional revenues of $6 \%$ and $11 \%$, respectively, are worthy of note.

The difference in the revenues of the two installations mentioned above can be explained by different shares of directly marketed capacity, which is higher for large biogas installations. Although in this model small biogas installations with a maximum installed capacity of $350 \mathrm{~kW}$ cannot participate in the balancing market, they still profit indirectly from the other installations' sales, as can be seen from Figure 3. This results from the model assumption that, due to the additional revenues achieved on the balancing market, the direct marketers will also increase bonus payments to their other customers which is a possibility to improve their competitive position.

Finally, by exploiting balancing markets, the flexibilisation of installations can indeed have a positive effect on their economic efficiency while also supporting the system as a whole. Thus, it appears to make sense to incentivise a corresponding adaptation of installations and to enable their participation in the balancing market, where besides storage plant operators more and more other new participants are competing.

Viewed on the whole, however, the market premium currently has the character of a 'curtailment premium': for intermittent renewables, curtailment signals become effective when electricity prices are highly negative; for dispatchable renewables, this occurs earlier due to positive marginal costs, especially since the supply of negative balancing energy is profitable. For bioenergy installations, in particular, the response to electricity price signals sets important incentives for optimising the use of biomass resources.

However, so far, the model sets few incentives for dispatchable renewables to engage in positive load shifting, which might be desirable in order to increase the contribution of RES to the energy supply when feed-in from intermittent RES is low, and could contribute to the stability of the system. At present, this is also determined by relatively low peak/off-peak spreads on the spot market [47]. Furthermore, there are still few incentives for dispatchable renewables to supply positive balancing energy or for intermittent renewables to make market value-oriented decisions about the design of their installations.

By reducing the quantity of electricity that has to be remunerated in times of low and negative prices, voluntary curtailment eases the EEG surcharge burden, which is determined on the basis of the difference between the feed-in tariff's or market premium's reference prices and the market value for RES electricity [6]. However, the ongoing expansion of intermittent RES with near-zero marginal costs and the high temporal coincidence of their feed-in causes the market value of intermittent renewables to fall $[25,48,49]$. Even if the full costs of RES generation were decreasing, this would in turn lead to an increasing burden on the EEG surcharge and represents a fundamental problem for the integration of intermittent RES in the 'energy only' market. Moreover, analyses of the causes of negative electricity prices show that in times of negative prices, in addition to nuclear power plants, particularly emission-intensive lignite coalfired power plants continue to operate at high load $[42,50]$. Here, RES curtailment reduces incentives for conventional power plant operators to curtail their operations or invest in flexibilisation measures. From the climate

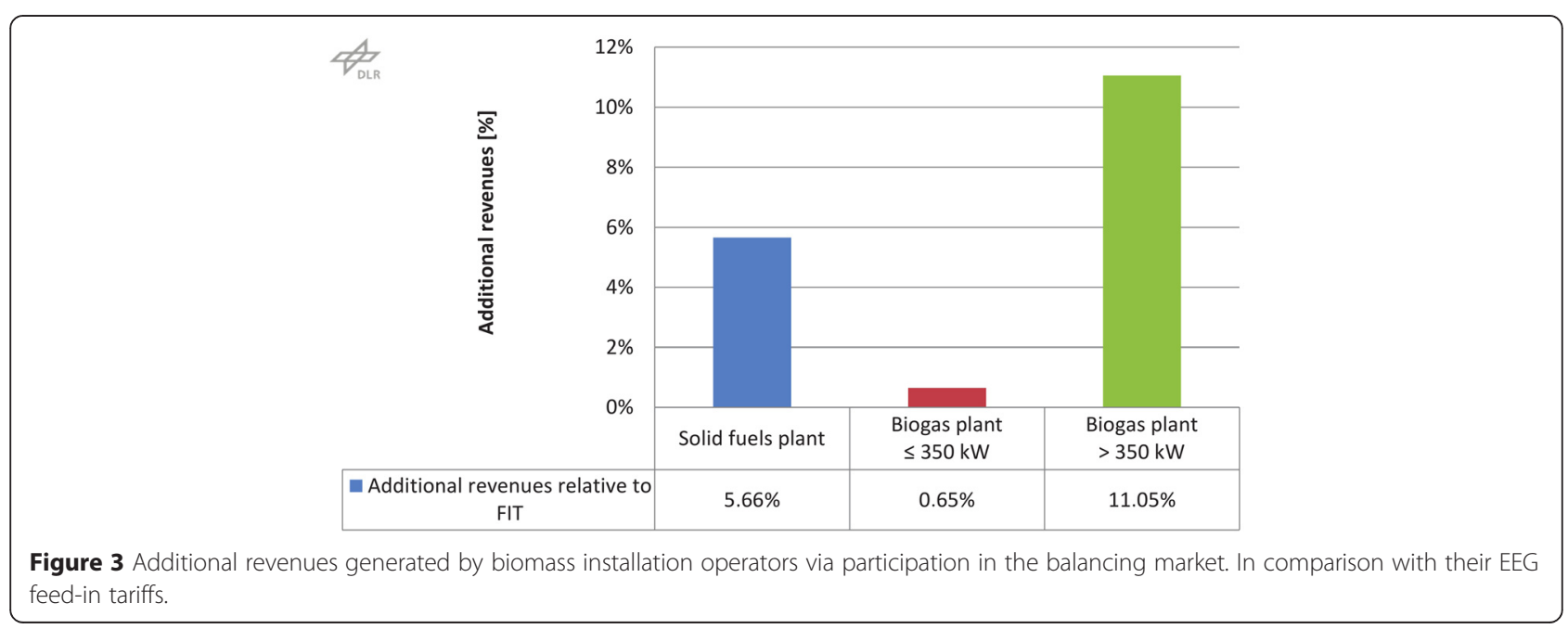


policy and system transformation perspective, this situation is highly problematic $[18,20,51]$.

The market premium under the EEG 2014 - a contribution to a more objective-based market integration?

The main changes in the EEG 2014 concerning RES market integration are the following: the mandatory character of direct marketing for larger, new installations; the pricing-in of the management premium in the reference prices used to calculate the market premium; cuts in payments when prices are negative for prolonged periods; and the introduction of remote control capability as a requirement for payment of the market premium. Further implications arise from the general decrease of remuneration rates, which is particularly pronounced for bioenergy [52]. So, the question is, compared with the EEG 2012, what changes can be expected regarding the contribution of the market premium to marketing efficiency and the promotion of demanddriven and flexible electricity feed-in?

In terms of marketing efficiency, the exploitation of the marketing channels used under the market premium model in the EEG 2012 seems likely to continue since there has been no change in the structure of the incentives created. For biogas installations, flexibility of operators to design site-specific marketing concepts is restricted by the newly introduced limit on the remunerated quantity of electricity to $50 \%$ of the installation's power rating [53]. In that respect, it lessens the advantage associated with direct marketing for these dispatchable RES of being able to optimise the marketing of electricity and heat to suit the specific installation. In particular, however, mandatory direct marketing in conjunction with the reduced management premium is expected to have a tendency to strengthen larger direct marketers who have lower marketing costs due to economies of scale and so can remain competitive [38]. The mentioned tendency and economic impact of the direct marketing costs in combination with a simultaneous abolition of the management premium were examined using the DLR simulation model described above (here, the obligation implies that the management premium paid out on top of the market premium under the EEG 2012 is no longer provided and is also not integrated in the reference prices, as is the case under the EEG 2014). The model accounts for fixed and variable costs of direct marketers, i.e. fixed costs represent office rents, IT and staffing costs and annual charges for trading, whereas variable costs refer to the amount of traded electricity and expenditures for electricity generation forecasts and balancing power needed in case of deviation from generation schedule. As depicted by Figure 4, by way of example, with the above-mentioned cost structure, the specific marketing costs of the direct marketers in
AMIRIS assume values between $€ 1$ per MWh and $€ 3.50$ per MWh for the simulation years 2012 to 2019. The grey-shaded area illustrates the variation of the marketing costs as they are depending on the type of trader. The extent of the costs is strongly dependent on the composition of the trader's portfolio - in contrast to dispatchable renewables, high shares of intermittent renewables tend to result in higher costs to balance generation and demand. The decrease of the maximum specific costs until 2019 is due to an increasing size of portfolios of the direct marketers, i.e. they profit from economies of scale and improved forecast qualities over the years. The simulated costs correspond quite accurately with estimates given by direct marketers based on experience and show the eligible configuration of the model.

If marketing costs were no longer compensated by the management premium, direct marketers' revenues would be reduced. Figure 5 shows AMIRIS simulation results for the overall profit of the marketers under assumption of a decreasing management premium according to the EEG 2012 (light grey area) and a complete abolition of the management premium (dark grey area). The overall profit is defined as the difference between total income and costs, and the areas represent the variation of results of the different simulated direct marketers. As can be seen, with a decreasing management premium, the majority of the marketers still gain positive overall profit; the reduction of the premium is reflected in the diminution of the profit over the years, with explicit gradient in 2012 and 2013. In contrast, the abolition of the premium implies negative profits for all simulated types of direct marketers, as the dark grey area depicts. The decrease of the minimum profit until 2019 reflects the increasing expenditures for payments

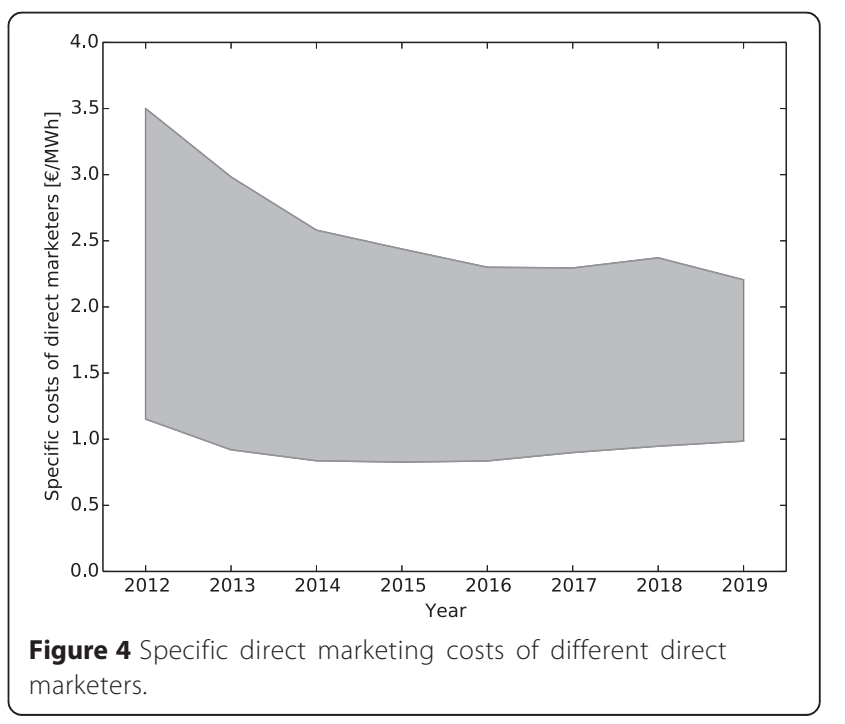




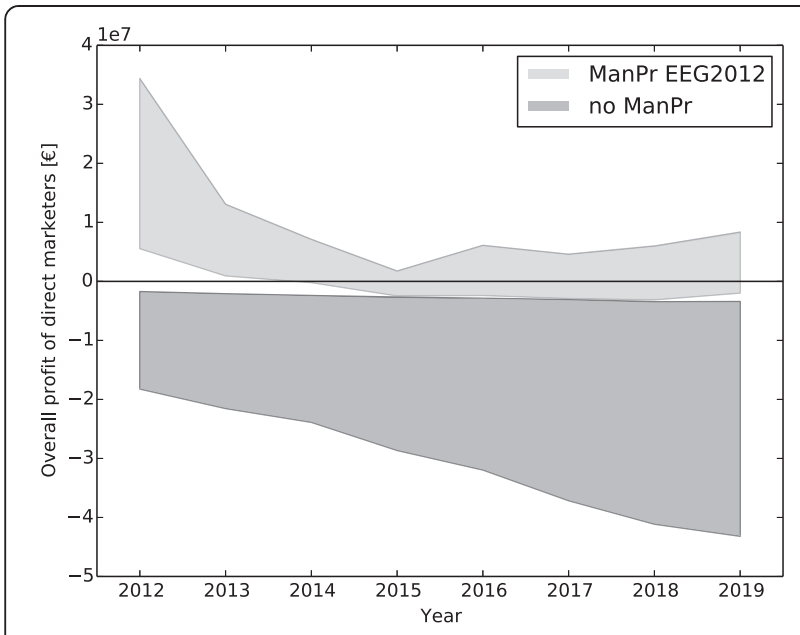

Figure 5 Overall profits of different direct marketers. Overall profits of different direct marketers in case of payment of a decreasing management premium according to EEG 2012 (light grey area) and in case of abolition of the management premium (dark grey area). Overall profits of direct marketers in tens of millions of euros.

to installation operators, as the portfolio of the direct marketers still grows in the simulation.

Profit losses are accompanied by an increased pressure to reduce costs that may lower the transaction costs of marketing and thus improve efficiency. But as not all direct marketers may have the possibility to reduce costs as needed, an oligopolisation in the direct marketers' market would weaken the bargaining power of RES producers [18]. Furthermore, direct marketers would have to 'retrieve' their costs from the installation operators in order to achieve an at least comparatively balanced account. This would mean that the specific direct marketing costs could also be interpreted by installation operators as a corresponding reduction of the remuneration rates.

Hence, these simulations point to the following possible risks:

- Market concentration: Direct marketers with large portfolios have comparatively lower marketing costs because economies of scale in power trading and the broad spatial distribution of RES feed-in installations reduce costs. This can lead to concentration effects and create dominant market positions for traders, whose market power can make conditions more difficult for further RES investments.

- Rising costs: If policy is aimed at preserving today's diversity among direct marketers and giving players with smaller portfolios a chance to compete in the market, it must allow higher specific marketing costs to be compensated, e.g. via a premium. The compensation premiums required to promote a heterogeneous market could subsequently result in rising costs of support for electricity from renewable energy sources.

- Lower remuneration: For installation operators, mandatory direct marketing without payment of compensation via the management premium implies an indirect reduction in remuneration in the amount of the specific marketing costs and a reasonable margin of profit for intermediaries. This effect could weaken investment incentives, especially for intermittent RES.

In contrast to the effects on intermittent renewable energy sources, the introduction of mandatory direct marketing for dispatchable renewables such as biomass installations presents a comparatively lower risk. In addition, bringing dispatchable renewables onto the market would increase their flexibilisation potential, provided the financing of a corresponding technological design is guaranteed.

The temporally unlimited fall-back option provided by $\$ 38$ EEG 2014, meanwhile, is essentially to be welcomed, as capital investors would otherwise impose significant risk premiums to account for cases where RES producers lose their direct marketers [18,38]. However, the $20 \%$ cut in remuneration results in substantial income losses so that the exploitation of the feed-in tariff in exceptional cases only provides a short-term option, which in turn strengthens the bargaining position of direct marketers. Producers are therefore all the more reliant on strong competition between direct marketers but precisely this competition may be diminished if economies of scale reduce the number of direct marketing companies. Meanwhile, the remuneration of RES generation increasingly depends on the conclusion of individual contracts and so predictability and transparency suffer. How this will be reflected in risk calculations and investment inclination still has to be examined.

Regarding the promotion of demand-oriented feed-in, it again makes sense to differentiate between dispatchable and intermittent renewables. In combination with revenue prospects associated with a participation in balancing markets, the market premium scheme under the EEG 2012 has set meaningful flexibilisation incentives for bioenergy plants, particularly for biogas installations eligible for the flexibility premium. In the EEG 2014, there are interactions between market integration incentives and the significant general cuts in remuneration for bioenergy. To what extent new biomass installations are economically feasible is questionable [52], so that the role of new installations as a flexibility option in the electricity system is likely to be limited. Although, in principle, the 
limit placed on the amount of electricity eligible for remuneration in the case of biogas installations provides an incentive to sell electricity at the highest possible price (see above), it is likely to deteriorate further the profitability of new installations. Furthermore, in terms of climate impacts, the one-sided focus of the eligibility requirements on flexibility should be evaluated critically because concepts involving high levels of heat use - which lead to higher reductions in greenhouse gas emissions compared to pure electricity production [54] - are neglected. Hence, as a flexibilisation option, mainly existing plants which can claim the market premium based on the remuneration under earlier versions of the EEG are likely to play a role. Here, a flexibility premium that includes solid fuelpowered biomass installations might have been appropriate in order to encourage the relevant changes in feed-in behaviour and make flexibilisation investments worthwhile [55].

On the side of intermittent renewables, the introduction of remote control capability as an eligibility requirement for new installations represents a sensible amendment [32]. Apart from this, the lack of responsiveness of intermittent renewables to electricity price signals beyond curtailments continues to be a problem, and it will only be aggravated by cutting remuneration in times of negative electricity prices. While the market premium under the EEG 2012 primarily served to prevent negative price spikes, the new regulation is aimed at curtailing production once prices fall below zero for six or more consecutive hours. This encourages intermittent RES producers with near-zero marginal costs to curtail production before continuously operating conventional power plants with positive marginal costs do so - a situation which, from efficiency and climate policy perspectives, does not appear advantageous. At the same time, the existence of 'moderate negative prices' [41], p. 104 , is considered to constitute an economically reasonable means of sending flexibilisation signals to the operators of conventional power plants $[5,18,41]$. However, the new regulation largely relieves the latter of responsibility for implementing the system transformation; RES operators tend to bear growing electricity price risks $[42,56]$, while the less frequent occurrence of negative prices benefits conventional power plant operators, who can avoid the costs of investing in flexibilisation. While the new regulation might ease the EEG surcharge burden in the short term, the long-term costs of transforming the electricity system can be expected to rise, since flexibility incentives for the system as whole are reduced.

\section{Conclusions}

In summary, it can be stated that the sliding premium, in the form in which it has been introduced in Germany, has made a positive contribution to the marketing efficiency of dispatchable RES in particular, because it allows for an individual optimisation of marketing concepts including participation in balancing markets. Meanwhile, the benefits of a greater demand orientation of RES feed-in remain limited when considering the extent to which load shifting is incentivised. As a result of the sharp cuts in the reference prices for bioenergy in the EEG 2014, the recently introduced extended flexibilisation requirements for biogas plants are likely to be relevant for only a small number of new installations. Whether incentives for existing installations will be sufficient in the long term to encourage load shifts beyond the supply of negative balancing energy remains to be investigated. For intermittent RES, incentives to encourage a change in feed-in behaviour are only effective in times of negative electricity prices when voluntary curtailment is encouraged. However, this simultaneously leads to a reduction in urgently needed flexibilisation signals to conventional power plants and other electricity market players, not least to the demand side or storage concepts. This problem is exacerbated by the EEG 2014's cuts in remuneration during prolonged negative electricity prices. Meanwhile the fundamental problem of the market integration of intermittent RES with nearzero marginal costs - the fact that an increase in feed-in amounts is associated with a decrease in market value remains unsolved.

Development trends in the market structure of direct marketing service providers towards few large players who can benefit from exploiting economies of scale and tendering broad RES portfolios on the spot market also show that direct marketing provides few structural changes compared to marketing through TSOs, at least in the case of intermittent RES. While the exploitation of economies of scale is linked to reductions in transaction costs and so can improve marketing efficiency, an oligopolisation in the direct marketers' market would represent a problematic development: insufficient competition between direct marketers would in particular weaken the bargaining position of intermittent RES operators, whose marketing is associated with higher costs compared to dispatchable renewables. This could have a negative impact on investment incentives.

So far, Germany's experiences with the market premium and direct marketing suggest that, for the further development of mechanisms to support greater market proximity, differentiating between the various RES according to their ability to respond to electricity price signals can prove advantageous $[1,19,20]$. Given the experience gained to date, it seems doubtful whether an increase in short-term electricity price risks can increase the efficiency of supply of intermittent RES, rather than just leading to higher risk premiums or reluctance to 
invest. Under these conditions, it has been suggested that rather than making direct marketing obligatory, it may be advantageous to allow intermittent RES producers a (non-reversible) choice between central marketing in combination with a low-risk but also low-profit margin feed-in tariff and direct marketing in combination with an instrument that promotes market integration more comprehensively than an administered sliding feed-in premium but compensates price risks with a chance of higher returns [19]. Candidates for such an instrument could be competitively determined feed-in or capacity premiums, the latter having the advantage of not distorting spot market price signals $[12,19,57]$. The continued marketing of intermittent RES by TSOs, on the other hand, would require improved access to production data and incentives to optimise central marketing of RES electricity. For dispatchable RES such as bioenergy, meanwhile, refinancing models which have a stronger competitive element in the determination of remuneration than the market premium could provide a promising option to encourage operators to design siteoptimised installation concepts, which also exploit heat marketing opportunities [19]. When designing support for new installations, it should, however, be taken into account that growing competition for cheap feedstocks could endanger the supply of raw materials and the profitability of existing plants [58].

Regarding the transition to competitive bidding processes as promoted in the EU energy aid guidelines, it is necessary to critically discuss the question of how a stronger integration of different RES in existing electricity markets can actually contribute to improving security of supply, reducing the costs of RES expansion and transforming the electricity system. The case study of the German market premium clearly points out that these targets cannot be reached through market integration efforts on the part of RES alone. Rather, electricity market conditions must also be adapted to the requirements of RES, and flexibilisation incentives are needed for other participants in the electricity market $[41,59]$. Considering the uncertainties and country-specific conditions that have to be taken into account in a combined reform of the design of the electricity market and RES support mechanisms, competition between systems with different approaches in the different member states could have advantages over a one-size-fits-all approach as formulated in the EU guidelines on state aid [60].

\section{Endnotes}

${ }^{\mathrm{a}}$ Calculated according to $[33,34]$ in conjunction with EEG 2012 Annex 4 and the Management Premium Ordinance (MaPrV) 2012 [35]. The exact value is determined by the share of intermittent RES installations that were eligible to claim the higher management premium rate for installations with remote control capability.

${ }^{\mathrm{b}}$ Wood gasifiers, which are still in an infant stage and do not play a significant role in the stock of biogas installations, are excluded from the assessment since they do not participate in direct marketing.

\section{Competing interests}

The authors declare that they have no competing interests.

\section{Authors' contributions}

Several authors drafted the different parts of the first version of this manuscript. All authors contributed to revising and finalising this article. All authors read and approved the final manuscript.

\section{Acknowledgements}

Joint research on this paper has been undertaken in the context of the Integrated Key Topic 'Regulation, Instruments, Governance' of the Alliance ENERGY-TRANS established by the Helmholtz Association of German Research Centres. Further information can be found at www.energy-trans.de. Furthermore, we would like to thank two anonymous reviewers for helpful comments.

\section{Author details}

${ }^{1}$ Department of Economics, Helmholtz Centre for Environmental Research - UFZ, Permoser Str. 15, Leipzig 04318, Germany. ${ }^{2}$ Institute for Infrastructure and Resources Management, University of Leipzig, Grimmaische Str. 12, Leipzig 04109, Germany. ${ }^{3}$ Department of Systems Analysis and Technology Assessment, Institute of Engineering Thermodynamics, German Aerospace Center (DLR), Wankelstr. 5, Stuttgart 70563, Germany. ${ }^{4}$ Stuttgart Research Center for Interdisciplinary Risk and Innovation Studies (ZIRIUS), University of Stuttgart, Seidenstr. 36, Stuttgart 70174, Germany.

Received: 5 December 2014 Accepted: 6 March 2015

Published online: 16 April 2015

\section{References}

1. Eclareon, Öko-Institut (2012) Integration of electricity from renewables to the electricity grid and to the electricity market - RES-INTEGRATION. Eclareon, Öko-Institut, Berlin, Freiburg

2. Imperial College London, Nera Economic Consulting, DNV GL (2014) Integration of renewable energy in Europe. Final report for the European Commission. Directorate-General Energy. DNV GL-Energy, Bonn

3. AEE (2014) Studienvergleich: Finanzierungsinstrumente für Strom aus erneuerbaren Energien. Metaanalyse von Vorschlägen für die künftige Finanzierung von Strom aus erneuerbaren Energien. Agentur für Erneuerbare Energien, Berlin

4. European Commission (2014) Guidelines on state aid for environmental protection and energy 2014-2020. Communication from the Commission (2014/C 200/01). Off J Eur Union C 200(28.6.2014):1-55

5. Lehnert W, Altrock M, Fouquet D, Vollprecht J, Nysten J, Dalibor M (2014) Vorbereitung und Begleitung der Erstellung des Erfahrungsberichts 2014 gemäß § 65 EEG im Auftrag des Bundesministeriums für Wirtschaft und Energie. Vorhaben III. Rechtliche und instrumentelle Weiterentwicklung des EEG. Wissenschaftlicher Bericht. Becker Büttner Held, Fraunhofer-ISI, Öko-Institut, Stiftung Umweltenergierecht, IKEM, Berlin

6. Klobasa M, Ragwitz M, Sensfuß F, Rostankowski A, Gerhardt N, Holzhammer U, Richts C, Lehnert W (2013) Nutzenwirkung der Marktprämie. Working paper sustainability and innovation no. S 1/2013. Fraunhofer-ISI, Karlsruhe

7. BMU (2011) Entwurf Erfahrungsbericht 2011 zum Erneuerbare-Energien-Gesetz (Stand 3.5.2011). BMU, Berlin

8. RES LEGAL (2014) Legal sources on renewable energy: renewable energy policy database. An initiative of the European Commission., http://www.res-legal.eu/. Accessed 10 Dec 2014

9. Gawel E, Purkus A (2013) Promoting the market and system integration of renewable energies through premium schemes - a case study of the German market premium. Energy Policy 61:599-609, doi:10.1016/j.enpol.2013.06.117 
10. Kitzing L, Mitchell C, Morthorst PE (2012) Renewable energy policies in Europe: converging or diverging? Energy Policy 51:192-201, doi:10.1016/j.enpol.2012.08.064

11. Monopolkommission (2013) Sondergutachten 65: Energie 2013: Wettbewerb in Zeiten der Energiewende. Sondergutachten der Monopolkommission gemäss § 62 EnWG. Monopolkommission, Bonn

12. Kopp O, Engelhorn T, Onischka M, Bode S, Groscurth H (2013) Wege in ein wettbewerbliches Strommarktdesign für erneuerbare Energien. MW Energie AG, arrhenius Institut für Energie- und Klimapolitik, Takon, Ecofys, Mannheim

13. Gawel E, Purkus A, Korte K, Lehmann P (2013) Förderung der Markt- und Systemintegration erneuerbarer Energien - Perspektiven einer instrumentellen Weiterentwicklung. Vierteljahreshefte zur Wirtschaftsforschung 82(03/2013):123-136

14. Klobasa M, Winkler J, Sensfuß F, Ragwitz M (2013) Market integration of renewable electricity generation - the German market premium model. Energy Environ 24(1-2):127-146

15. Sensfuss F, Ragwitz M (2011) Weiterentwickeltes Fördersystem für die Vermarktung von erneuerbarer Stromerzeugung. Fraunhofer-|S|, Karlsruhe

16. EEX, EPEX Spot (2014) Positionspapier zur Weiterentwicklung der Fördermechanismen für erneuerbare Energien in Deutschland. European Energy Exchange, EPEX Spot, Leipzig, Paris

17. Bardt H (2014) EEG 2.0. Ein zweiter Schritt muss folgen. IW policy paper 5/ 2014. IW Institut der deutschen Wirtschaft Köln, Köln

18. IZES (2014) Herausforderungen durch die Direktvermarktung von Strom aus Wind Onshore und Photovoltaik. Greenpeace, Hamburg

19. IZES, Bofinger P, BET (2013) Stromsystem-Design: Das EEG 2.0 und Eckpfeiler eines zukünftigen Regenerativwirtschaftsgesetzes. IZES, Prof. Dr. Peter Bofinger, BET Büro für Energiewirtschaft, Saarbrücken, Würzburg, Aachen

20. Jacobs D, Schäuble D, Bayer B, Sperk C, Töpfer K (2014) Eckpunkte für die Gestaltung der Energiewende. IASS policy brief 2/2013. Institute for Advanced Sustainability Studies (IASS), Potsdam

21. Reeg M (2014) Entwurf eines ganzheitlichen Strommarktdesigns fü hohe Anteile erneuerbarer Energien - Flexibilität statt reiner Kapazität. Diskussionspapier 01/2014 der Abteilung Systemanalyse und Technikbewertung. DLR, Stuttgart

22. Pahle M, Tietjen O, Joas F, Knopf B (2014) EE Förderinstrumente \& Risiken: Eine ökonomische Aufarbeitung der Debatte zur EEG Reform. Diskussionspapier. Potsdam-Institut für Klimafolgenforschung PIK, Potsdam

23. Diekmann J, Kemfert C, Neuhoff K, Schill W-P, Traber T (2012) Erneuerbare Energien: Quotenmodell keine Alternative zum EEG. DIW Wochenbericht 45/2012. DIW, Berlin

24. Reeg M, Elkadragy MM (2014) Changed risk premiums and equity debt requirements due to different RES-E policy instruments for market integration of renewable energies in Germany. Paper presented at the 14th IAEE European energy conference - sustainable energy policy and strategies for Europe, Rome, Italy, 28-31 Oct 2014

25. Reeg M, Nienhaus $K$, Roloff N, Pfenning U, Deissenroth M, Wassermann S, Hauser W, Weimer-Jehle W, Kast T, Klann U (2013) Weiterentwicklung eines agentenbasierten Simulationsmodells (AMIRIS) zur Untersuchung des Akteursverhaltens bei der Marktintegration von Strom aus erneuerbaren Energien unter verschiedenen Fördermechanismen. Projektbericht. DLR, Stuttgart

26. Nienhaus K, Deissenroth M, Reeg M (2014) Policy instruments and market integration of renewables - an agent-based model analysis. Paper presented at the 14th IAEE European energy conference - sustainable energy policy and strategies for Europe, Rome, Italy, 28-31 Oct 2014

27. Wassermann S, Reeg M, Nienhaus K (2015) Current challenges of Germany's energy transition project and competing strategies of challengers and incumbents: the case of direct marketing of electricity from renewable energy sources. Energy Policy 76:66-75, doi:10.1016/j. enpol.2014.10.013

28. Kahl H, Kahles M, Merkel K (2014) Rechtlicher Klärungsbedarf zu Ausschreibungsmodellen bei der Förderung erneuerbarer Energien. Würzburger Berichte zum Umweltenergierecht Nr. 7, Würzburg

29. 50Hertz, Amprion, TenneT, Transnet BW (2014) Aktuelle Informationen zu den EEG-Strommengen: Monatsprognosen. Direktvermarktung nach $\S 33 \mathrm{~b}$ EEG. http://www.netztransparenz.de/de/Monatsprognosen.htm. Accessed 10 Dec 2014

30. Bundesnetzagentur (2014) Kraftwerksliste BNetzA Stand 02.04.2014. http://www.bundesnetzagentur.de/DE/Sachgebiete/ElektrizitaetundGas/
Unternehmen_Institutionen/Versorgungssicherheit/Erzeugungskapazitaeten/ Kraftwerksliste/kraftwerksliste-node.html. Accessed 10 Dec 2014

31. Lüdemann V, Ortmann M (2012) Hält die Marktprämie, was sie verspricht? Eine Analyse anhand aktueller Zahlen. Zeitschrift für Neues Energierecht (ZNER) (4/20124):325-334

32. Beckers T, Hoffrichter A (2014) Grundsätzliche und aktuelle Fragen des institutionellen Stromsektordesigns - eine institutionenökonomische Analyse zur Bereitstellung und Refinanzierung von Erzeugungsanlagen mit Fokus auf FEE. Arbeitspapier. TU Berlin, Fachgebiet Wirtschafts- und Infrastrukturpolitik (WIP), Berlin

33. 50Hertz, Amprion, Tennet, Transnet BW (2013) EEG-Jahresabrechnungen 2012 (Stand: 26.07.2013). http://www.netztransparenz.de/de/file/2012 EEG-Jahresabrechnung_.pdf. Accessed 10 Dec 2014

34. 50Hertz, Amprion, Tennet, Transnet BW (2014) EEG-Jahresabrechnungen 2013 (Stand: 25.07.2014). http://www.netztransparenz.de/de/file/EEG_ HoBA_2013_20140725.pdf. Accessed 10 Dec 2014

35. MaPrV (2012) Verordnung über die Höhe der Managementprämie für Strom aus Windenergie und solarer Strahlungsenergie (Managementprämienverordnung - MaPrV) vom 2. November 2012 (BGBI. I S. 2278)

36. Fraunhofer-ISI, Fraunhofer-IWES, BBH, IKEM (2012) Anpassungsbedarf be den Parametern des gleitenden Marktprämienmodells im Hinblick auf aktuelle energiewirtschaftliche Entwicklungen. Fraunhofer-ISI, Karlsruhe

37. Munz I, Paltauf A, Walter G (2013) Subventionen für erneuerbare Energien in Deutschland. Das Marktprämienmodell und weitere Entwicklungen. Branche STROMMARKT Bulletin (5/2013):24-27

38. Energy Brainpool (2013) Auswirkungen der verpflichtenden Direktvermarktung für EEG-Neuanlagen. Kurzstudie im Auftrag des Bundesverbands Erneuerbare Energien e. V. Energy Brainpool, Berlin

39. Holzhammer U, Stelzer M (2014) Die Direktvermarktung: Aktueller Stand, Möglichkeiten und Ausblick. Paper presented at the Fachtagung Dezentrale flexible Strombereitstellung aus Biogas - Entwicklungen, Möglichkeiten und Perspektiven, Berlin, 03 April 2014

40. Wassermann S, Reeg M, Hauser W (2012) Auswirkungen der Marktprämie auf die Akteure der Direktvermarktung - ein agentenbasierter Modellansatz. Energiewirtschaftliche Tagesfragen 62(9):60-63

41. Connect Energy Economics (2014) Leitstudie Strommarkt. Arbeitspaket Optimierung des Strommarktdesigns. Studie im Auftrag des Bundesministeriums für Wirtschaft und Energie. Connect Energy Economics, Berlin

42. Götz P, Henkel J, Lenck T, Lenz K (2014) Negative Strompreise: Ursachen und Wirkungen. Eine Analyse der aktuellen Entwicklungen - und ein Vorschlag für ein Flexibilitätsgesetz. Energy Brainpool, Agora Energiewende, Berlin

43. Waldmann P, Bhandari R (2014) Vergleichende Analyse der technischwirtschaftlichen Bedingungen von PV-Anlagen mit Süd- und Ost-West-Ausrichtung. Zeitschrift für Energiewirtschaft 38(1):27-36, doi:10.1007/s12398-013-0123-7

44. Grothe O, Müsgens F (2013) The influence of spatial effects on wind power revenues under direct marketing rules. Energy Policy 58:237-247, doi:10.1016/j.enpol.2013.03.004

45. Häseler S (2014) Procuring flexibility to support Germany's renewables: policy options. Zeitschrift für Energiewirtschaft 38(3):151-162, doi:10.1007/s12398-014-0128-x

46. Krautz A (2013) Anlagen flexibel betreiben? DLG Mitteilungen (5/2013):46-49

47. Fraunhofer-IWES, Becker Büttner Held, Deutsche Windguard, Deutsches Institut für Wirtschaftsforschung (DIW Berlin), Leibniz Universität Hannover (2011) Flexible Stromproduktion aus Biogas und Biomethan. Die Einführung einer Kapazitätskomponente als Förderinstrument. Bericht zum Projekt "Weiterentwicklung und wissenschaftliche Begleitung der Umsetzung des Integrations-Bonus nach § 64 Abs. 1.6 EEG" im Auftrag des Bundesministeriums für Umwelt Naturschutz und Reaktorsicherheit (BMU). Fraunhofer Institut für Windenergie und Energiesystemtechnik (IWES), Kassel/Bremerhaven

48. Kopp O, Eßer-Frey A, Engelhorn T (2012) Können sich erneuerbare Energien langfristig auf wettbewerblich organisierten Strommärkten finanzieren? Zeitschrift für Energiewirtschaft 36(4):243-255, doi:10.1007/s12398-012-0088-y

49. Hirth $L$ (2013) The market value of variable renewables: the effect of solar wind power variability on their relative price. Energy Econ 38:218-236, doi:10.1016/j.eneco.2013.02.004 
50. Fraunhofer-ISE (2013) Kohleverstromung zu Zeiten niedriger Börsenstrompreise. Fraunhofer-ISE, Freiburg

51. Carstensen UT, Schulze L, von Geldern W (2013) Deutschland braucht ein Marktmodell Energiewende - ein Masterplan zur Energiewende. Zeitschrift für Neues Energierecht (ZNER) (6/2013):581-591

52. Thrän D, Krautz A, Scheftelowitz M, Lenz V, Liebetrau J, Daniel-Gromke J, Zeymer M, Nelles M (2014) Auswirkungen der gegenwärtig diskutierten Novellierungsvorschläge für das EEG-2014. Deutsches Biomasseforschungszentrum, Leipzig

53. Krautz A (2014) Bedarfsgerechte Anlagen passen sich den Marktbedingungen an - Zwischenbericht des Forschungsprojektes OptFlex Biogas. Paper presented at the Fachtagung Dezentrale flexible Strombereitstellung aus Biogas: Entwicklungen, Möglichkeiten und Perspektiven, Berlin, 03 April 2014

54. Lansche J, Müller J (2012) Life cycle assessment of energy generation of biogas fed combined heat and power plants: environmental impact of different agricultural substrates. Eng Life Sci 12(3):313-320, doi:10.1002/ elsc.201100061

55. DBFZ, Fraunhofer IWES, INL, Bosch \& Partner, UFZ (2014) Vorbereitung und Begleitung der Erstellung des Erfahrungsberichts 2014 gemäß § 65 EEG. Vorhaben Ila: Stromerzeugung aus Biomasse. Wissenschaftlicher Bericht. Deutsches Biomasseforschungszentrum, Leipzig

56. Energy Brainpool (2014) Zukünftige Auswirkungen der Sechs-Stunden-Regelung gemäß § 24 EEG 2014. Kurzstudie im Auftrag des Bundesverbands WindEnergie e. V. Energy Brainpool, Berlin

57. ̈̈ko-Institut (2014) Erneuerbare-Energien-Gesetz 3.0. Konzept einer strukturellen EEG-Reform auf dem Weg zu einem neuen Strommarktdesign. Agora Energiewende, Berlin

58. Purkus A, Röder M, Gawel E, Thrän D, Thornley P (2015) Handling uncertainty in bioenergy policy design - a case study analysis of UK and German bioelectricity policy instruments. Biomass Bioenergy, doi:10.1016/j. biombioe.2015.03.029

59. Leprich U, Hauser E, Grashof K, Grote L, Luxenburger M, Sabatier M, Zipp A (2012) Kompassstudie Marktdesign. Leitideen für ein Design eines Stromsystems mit hohem Anteil fluktuierender erneuerbarer Energien. BEE-Plattform System Transformation. Ponte Press, Bochum

60. Gawel E, Strunz S (2014) State aid dispute on Germany's support for renewables: is the commission on the right course? J Eur Environ Plan Law 11(2):137-150

\section{Submit your manuscript to a SpringerOpen ${ }^{\circ}$ journal and benefit from:}

- Convenient online submission

- Rigorous peer review

- Immediate publication on acceptance

- Open access: articles freely available online

- High visibility within the field

- Retaining the copyright to your article

Submit your next manuscript at $\gg$ springeropen.com 